\title{
Mind maps produced by visual impaired students.
}

\author{
Luciana Maria Santos de Arruda ${ }^{\mathrm{a},}$, Carla Cristina Reinaldo Gimenes de Sena ${ }^{\mathrm{b}}$, \\ ${ }^{a}$ Instituto Benjamin Constant, luciana.maria.arruda@gmail.com, \\ ${ }^{b}$ Unesp, cacrisusp@gmail.com \\ * Corresponding author
}

Keywords: mind maps, tactile cartography, landscapes

\begin{abstract}
:
This paper presents part of the results obtained by a master's research entitled "Teaching of Geography to visually impaired students: new methodologies to discuss the concept of landscape". The data collected was the result of 8 years' experience in teaching Geography to visually impaired students at the Benjamin Constant Institute (IBC), a school in Rio de Janeiro specialized in teaching blind and visual impaired students for over 150 years. This study was motivated by the difficulty such students face during the learning process of geographic concepts.
\end{abstract}

The hypothesis raised during the research was that the use of didactic materials, which include the senses other than sight, mitigate such difficulties by enabling alternative sensorial paths. We chose the topic landscapes and the representation forms of such an important category in Geography.

Three visually impaired students (blind) were asked to represent the landscapes they find during their daily trip to school, highlighting their own perceptions, and how the other senses collaborate to the apprehension of the landscape. Each student drew and described his route. According to Kozel (2007, p.120), "the concept of lived world, brought by phenomenology, works as meaningful input to understand mental maps". Therefore, these maps represent the world, in which the students are inserted.

Student 1 - Lives in Japeri, state of Rio de Janeiro, $84 \mathrm{~km}$ far from the Institute. In his drawing, he chose to depict streets close to his house, the Institute, the train service line Central do Brasil and the beaches. He did not place the items in correct order: the drawings were placed side-by-side.

Student 2 - Lives in Honório Gurgel, a neighborhood in the north region of the city of Rio de Janeiro, 33km far from the Institute. He walks to the train station in Honório Gurgel. He states that he can apprehend and identify the surroundings of his house and the changes that occur throughout the day. In his drawing, he chose to depict the entire path from his house to school, including all details he was able to apprehend. His notion of laterality, space and distance is very keen. This means he understands well the spatial organization of his neighborhood and his path to the Institute.

Student 3 - Lives in Duque de Caxias, 33km far from the Institute. He wakes up daily at $4 \mathrm{~h} 30$. He also apprehends the silence and the small number of people and cars on the streets. When he leaves home, he has his mental map ready, indicating how he must proceed, in order to get to the Institute. "When I leave home, I already have my mental map analyzed and planned". He chose to draw the main points of his path, starting with the train station Central do Brasil, where he arrives by bus, followed by the beaches Aterro do Flamengo, and finally the Institute. He arranged all places according to his commuting.
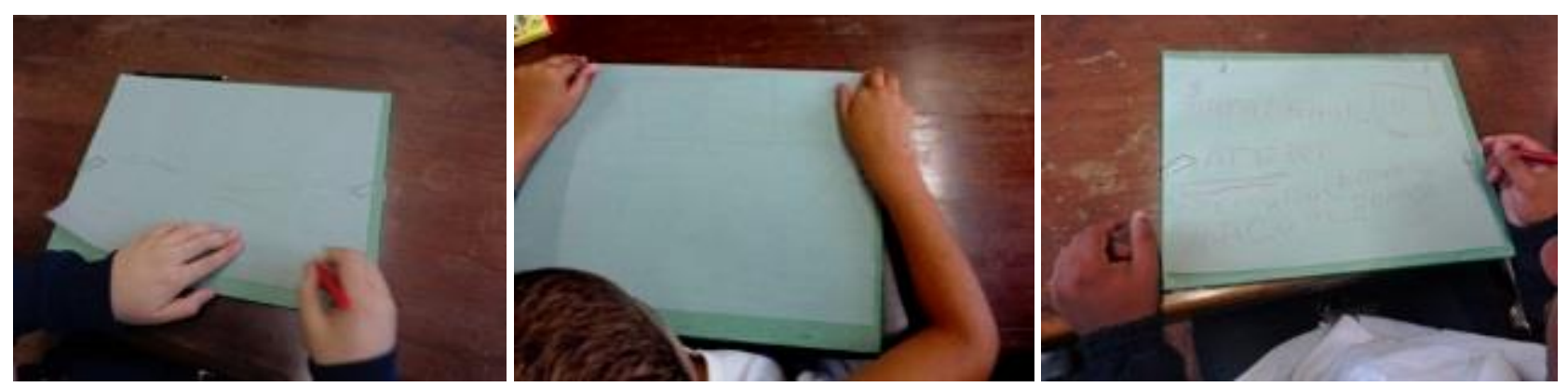

Figure 1: Students drawing the landscape they apprehend in the path from their houses to school

The development of the research showed the importance of mental maps for the spatial organization of people with disabilities. It also showed how they use other senses to apprehend their surroundings. After the activity, it was possible to build a model with texture and sound, so that the students could compare their own perceptions with the representation 
of the path from their houses to the Institute. It is important to use multisensorial didactic materials elaborated according to tactile cartographic techniques, so that visually impaired students have quality throughout their learning process.

\section{References:}

ARRUDA, L. M. S. O ensino de Geografia para alunos com deficiência visual: novas metodologias para abordar o conceito de paisagem. Dissertação de mestrado. Uberlândia, 2014. p. 149.

KOZEL, Salete. Mapas mentais - uma forma de linguagem: perspectivas metodológicas. In: KOZEL, Salete; SILVA, Josué da Costa; FILHO, Sylvio Fausto (Orgs). Da percepção e cognição a representação: reconstruções teóricas da Geografia Cultural e Humanista. São Paulo: Terceira Margem; Curitiba, 2007. 